\title{
Wanprestasi dalam Perjanjian Sewa Menyewa Rumah (Studi Penelitian Di Dusun A Desa Panggoi Kecamatan Muara Dua Kota Lhokseumawe)
}

\author{
Yuliani $^{1}$, Nanda Amalia ${ }^{2}$, Tri Widya Kurniasari ${ }^{3}$ \\ ${ }^{1}$ Alumni Mahasiswa Hukum Universitas Malikussaleh \\ ${ }^{12}$ Dosen Fakultas Hukum Universitas Malikussale
}

\begin{abstract}
This study discusses the legal relationship between the homeowner and the tenants of the house in a lease agreement. The lease provisions are regulated in Articles 1548 to 1600 Civil Code, but specifically based on the principle of consensualism of the parties. The legal relationship that occurs is in the form of a rental agreement. That this agreement was made legally by the parties and fulfilled the subjective and objective legal requirements, but in the implementation of the party renting out the promise to not deliver the object of the lease to the lessee and entered into a sale and purchase agreement with another party, this would cause a loss for the lessee. This study specifically raised 1 (one) case of default that occurred in a lease agreement with object 1 (unit) of a house located in Hamlet A, Panggoi Village, Muara Dua District, Lhokseumawe City. 3 (three) issues raised in this study are: 1). What is the legal relationship between the parties in the implementation of the rental agreement to rent a house in Hamlet A, Panggoi Village, Muara Dua District, Lhokseumawe City? 2). What will be the legal consequences for the parties in the lease agreement in Dusun A, Panggoi Village, Muara Dua District, Lhokseumawe City if there is a default? 3). What is the settlement effort made by the injured party due to default in the lease agreement? The analysis in this study was carried out qualitatively with an empirical juridical approach to see how the lease contracts that have been agreed by the parties are carried out by both. The data search is carried out through documentation study activities by examining various legal provisions especially the articles related to the lease agreement in the Civil Code and juxtaposing it with the contract agreed upon by the parties. Documentation study is supported by field study activities that interview the parties, namely the tenants and the renting parties as well as other respondents. With regard to the problem in question, the parties agreed to settle the family by holding a meeting. The lessee in this case does not sue the lessee to the litigation route through a breach of tort or tort against the law. For the lessee, the payment of the full payment which has been paid in full is sufficient to resolve the problem. This is motivated by the tenant not to complicate the problem of the loss he experienced. This study advises readers in particular and all parties to apply the principles of good faith and the principle of prudence in the implementation of the agreement, even though the agreements referred to are the types of agreements that are commonly carried out by the community as well as this lease agreement.
\end{abstract}

Key Words:Wanprestasi, Law, Homeowner, tenants 


\section{A. PENDAHULUAN}

Perjanjian adalah suatu peristiwa dimana seorang berjanji kepada seorang lain atau dimana dua orang itu saling berjanji untuk melaksanakan sesuatu hal. Perjanjian harus memenuhi syarat sahnya perjanjian, sebagaimana yang tertuang dalam Pasal 1320 Kitab Undang-Undang Hukum Perdata (KUH Perdata), yaitu sepakat mereka yang mengikatkan dirinya, kecakapan untuk membuat suatu perikatan, suatu hal tertentu, dan suatu sebab yang halal. Dengan terpenuhinya empat syarat sahnya perjanjian, maka secara hukum adalah mengikat bagi para pihak yang membuatnya. Perjanjian merupakan sumber terpenting yang melahirkan perikatan.

Eksistensi perjanjian sebagai salah satu sumber perikatan dapat kita temui landasannya pada ketentuan Pasal 1233 KUH Perdata yang menyatakan bahwa tiap-tiap perikatan dilahirkan, baik karena perjanjian baik karena undang-undang. Ketentuan tersebut dipertegas lagi dengan rumusan ketentuan Pasal 1313 KUHPerdata, yang menyatakan bahwa suatu perjanjian adalah suatu perbuatan di mana satu orang atau lebih mengikatkan diri terhadap satu orang lain atau lebih. Bentuk-bentuk perjanjian dapat dibedakan menjadi dua macam yaitu secara tertulis dan lisan. Perjanjian tertulis adalah suatu perjanjian yang dibuat oleh para pihak dalam bentuk tulisan, sedangkan perjanjian lisan adalah suatu perjanjian yang dibuat oleh para pihak dalam wujud lisan, cukup dengan kesepakatan para pihak tanpa dituangkan di dalam tulisan. Perjanjian yang dibuat secara lisan/tidak tertulis tetap mengikat dan tidak menghilangkan, baik hak dan kewajiban dari pihak yang bersepakat (Marhainis Abdul Hay, 1984). Dalam realitas kehidupan manusia - selain perjanjian jual beli, perjanjian sewa menyewa juga merupakan bentuk perjanjian yang kerap dilakukan oleh manusia di dalam memenuhi kebutuhan kehidupannya.

Sewa menyewa adalah suatu penyerahan barang oleh pemilik kepada orang lain itu untuk memulai dan memungut hasil dari barang itu dan dengan syarat pembayaran uang sewa menyewa oleh pemakai kepada pemilik aslinya. Selain itu, perjanjian sewa menyewa juga dimaknai sebagai suatu perjanjian dimana pihak yang satu mengikatkan kepada pihak lain kenikmatan dari suatu barang selama suatu waktu tertentu dengan pembayaran suatu harga yang oleh pihak lain disanggupi pembayarannya. Perjanjian sewa menyewa bertujuan untuk memberikan hak pemakaian saja kepada pihak penyewa. Pada perjanjian sewa menyewa yang dipentingkan adalah hak perorangan dan bukan hak kebendaan. Pihak yang menyewakan menyerahkan suatu 
barang yang hend1ak disewa kepada pihak penyewa untuk dinikmati sepenuhnya (Abdulkadir Muhammad, 1990).

KUHPerdata tidak menyebutkan

secara tegas mengenai bentuk perjanjian sewa menyewa sehingga sewa menyewa dapat dibuat dalam bentuk lisan maupun tertulis. Bentuk perjanjian sewa menyewa dalam praktek pada umumnya dibuat secara tertulis untuk mempermudah pembuktian hak dan kewajiban para pihak di kemudian hari, terutama pada perjanjian sewa menyewa barang yang nilainya besar dan dilakukan dalam jangka waktu yang lama. Pada dasarnya suatu perjanjian baik sewa menyewa maupun yang lainnya akan berlangsung dengan baik jika para pihak yang melakukan perjanjian tersebut dilandasi oleh itikad baik (good faith), namun apabila salah satu pihak tidak beritikad baik atau tidak melaksanakan kewajibannya maka akan timbul perbuatan wanprestasi atau ingkar janji. Hal tersebut akan memicu suatu perbuatan yang melanggar ketentuan Pasal 1365 KUHPerdata yaitu tiap perbuatan melanggar hukum yang membawa kerugian kepada seorang lain mewajibkan orang yang karena salahnya menerbitkan kerugian itu mengganti kerugian tersebut (Ahmadi Miru,2007).

Hubungan sewa menyewa dengan perorangan sangatlah erat karena sering terjadi dalam kehidupan sehari-hari disebabkan masyarakat tidak mampu hidup tanpa bantuan dari pihak lain seperti menyewakan barang yang berada pada pihak lain. Sewa menyewa yang sering terjadi dalam masyarakat yaitu sewa menyewa rumah atau bangunan, baik untuk pihak perorangan maupun kelompok. Dalam sewa menyewa rumah tersebut, kebanyakan para pihak sering melakukan kesalahan baik pihak pemilik rumah maupun pihak penyewa rumah sehingga menimbulkan perselisihan kedua belah pihak. Ada sebagian pihak penyewa tidak membayarkan uang sewa menyewa sebagaimana yang diperjanjikan yang telah ditetapkan oleh pihak pemilik rumah sehingga pihak pemilik rumah tidak bisa menerima atas perbuatan penyewa tersebut. Ada juga sebagian pihak pemilik rumah yang tidak menepati janjinya dengan menyewakan rumah yang telah disewakan kepada pihak lain tanpa memberitahukan kepada pihak penyewasebelumnya bahkan ada sebagian pemilik rumah setelah menerima uang muka sewa menyewa rumah namun tidak mengembalikannya kepada pihak penyewa.

Hal sebagaimana yang telah penulis gambarkan di atas terjadi di Dusun A Desa Panggoi Kecamatan Muara Dua Wilayah Kota Lhokseumawe. Pihak penyewa menjelaskan bahwa dirinya telah menyewa satu unit bangunan rumah permanen yang terdiri dari 2 (dua) 
kamar tidur dan 1 (satu) kamar mandi dengan dinding batu bata yang disewakan selama 3 (tiga) tahun dan harga sewa senilai Rp. 14.500.000,(empat belas juta lima ratus ribu rupiah). Penyewa tersebut telah membayarkan uang muka sewa sebanyak Rp. 2.500.000,- (dua juta lima ratus ribu rupiah) sebagai jaminan kesungguhannya untuk menyewa rumah tersebut kepada pemilik rumah. Setelah membayarkan uang muka sewa menyewa, pihak penyewa tidak langsung menempati rumah tersebut dikarenakan permintaan dari si pihak yang menyewakan untuk mengganti terlebih dahulu kunci-kunci rumah. Perjanjian sewa menyewa ini dilakukan oleh kedua belah pihak dan dituangkan dalam surat perjanjian sewa menyewa sederhana, ditandatangani oleh kedua belah pihak di atas materai sejumlah Rp. 6.000,- (enam ribu rupiah) tanpa melibatkan pihak lain sebagai saksi.

Dalam surat perjanjian tersebut (terlampir) telah diuraikan poin-poin yang harus dipatuhi oleh kedua belah pihak dan tidak boleh dilanggar oleh keduanya. Setelah menerima uang muka sewa menyewa rumah tersebut, pihak pemilik rumah atau pihak yang menyewakan justru melanggar isi perjanjian, dalam hal mana dirinya melakukan perjanjian jual beli kepada pihak ketiga terhadap objek sewa menyewa tersebut tanpa memberitahukan kepada pihak penyewa secara patut dan layak. Hal tersebut membuat pihak penyewa merasa dirugikan akibat pihak pemilik rumah telah ingkar janji atas kesepakatan yang telah ditulis dalam surat perjanjian (Zulfikar Hanif, 2019). Studi ini secara khusus akan membahas hubungan hukum antara pihak penyewa dengan pihak yang menyewakan rumah dan akibat hukum yang timbul dari hubungan dimaksud serta bagaimana langkah-langkah yang dipilih oleh para pihak di dalam menyelesaikan masalahnya, dengan mengangkat judul penelitian sebagai berikut "Wanprestasi dalam Perjanjian Sewa Menyewa Rumah (Studi Penelitian Di Dusun A Desa Panggoi Kecamatan Muara Dua Kota Lhokseumawe).

\section{B. METODE PENELITIAN}

Jenis penelitian ini merupakan penelitian kualitatif, yang dipakai sebagai prosedur penelitian yang menghasilkan data deskriptif mengenai permasalahan terkait dengan hubungan hukum serta akibat hukum bagi pihak yang wanprestasi dalam perjanjian sewa menyewa rumah di Dusun A Desa Panggoi Kecamatan Muara Dua Kota Lhokseumawe yang diuraikan dari pengamatan atas kata-kata tertulis dalam bentuk dokumen maupun dari lisan orang-orang atau perilaku yang dilakukan oleh orang-orang, dalam hal ini Pihak Penyewa dan Pihak Yang Menyewakan (Lexy J Moleong,2000). 


\begin{abstract}
Penelitian ini menggunakan pendekatan yuridis empiris (Amiruddin,2012), yaitu suatu pendekatan yang bertujuan melihat kesesuaian berbagai peraturan terkait dengan pelaksanaan hubungan hukum, bentuk hak dan kewajiban para pihak dalam pelaksanaan perjanjian sewa menyewa dengan objek sewa berupa rumah tinggal yang berlokasi di Dusun $A$ Desa Panggoi Kecamatan Muara Dua Kota Lhokseumawe. Studi ini akan menjelaskan hubungan hukum yang terjalin diantara keduanya serta akibat hukum yang timbul ketika wanprestasi terjadi. Studi ini juga akan menjelaskan bagaimana para pihak menyelesaikan permasalahannya.

Penelitian bersifat deskriptif analisis yaitu penelitian yang menghasilkan data yang deskriptif analisis dengan metode yang dipakai untuk menggambarkan suatu kondisi dan keadaan yang berlangsung supaya objek penelitiannya berdasarkan teori hukum atau peraturan perundangundangan yang berlaku (Amiruddin,2012).
\end{abstract}

\section{Hasil Penelitian}

Secara umum ketentuan terkait dengan perjanjian telah diatur dalam Pasal 1313 KUH Perdata yang menjelaskan bahwa perjanjian adalah suatu perbuatan dengan mana satu orang atau lebih mengikatkan dirinya terhadap satu orang atau lebih lainnya. Ketentuan lebih lanjut terkait dengan syarat sah perjanjian diatur dalam Pasal 1320 KUH Perdata, yaitu sebagai berikut:

1. Sepakat bagi mereka yang mengikatkan dirinya, maksudnya yaitu adanya kesepakatan kedua belah pihak dalam melakukan perjanjian tanpa adanya keterpaksaan oleh salah satu pihak.

2. Kecakapan untuk membuat suatu perikatan yang artinya pihak yang membuat kontrak tersebut sudah dewasa, mereka yang berada di bawah pengampuan dan bagi seorang istri harus sudah bersuami.

3. Suatu hal tertentu, maksudnya yaitu harus adanya barang (obyek) yang jelas dalam membuat perjanjian tersebut.

4. Suatu sebab yang halal artinya suatu kontrak harus dibuat dengan kausa beralasan tertentu sesuai dengan hukum yang berlaku.

Ketentuan Pasal 1338 ayat (1) KUH Perdata secara khusus telah memberikan pengaturan bahwa semua perjanjian yang dibuat secara sah berlaku sebagai undang-undang bagi yang membuatnya dan ayat (2) menjelaskan bahwa suatu perjanjian tidak dapat ditarik kembali selain dengan sepakat kedua belah pihak, 
atau karena alasan-alasan yang oleh undang-undang dinyatakan cukup itu. Hal ini membawa implikasi bahwa setiap pihak yang mengadakan perjanjian sepanjang memenuhi ketentuan dan syarat sahnya, maka perjanjian dimaksud adalah mengikat bagi keduanya.

Membicarakan secara khusus mengenai perjanjian yang dilakukan oleh para pihak, pada dasarnya perjanjian sewa menyewa telah mendapatkan pengaturan khusus dalam ketentuan KUHPerdata, pada Buku Ketiga, Bab VII tentang Sewa Menyewa, dimulai pada Pasal 1548 sampai dengan Pasal 1600. Ketentuan Pasal 1548 KUHPerdata menyatakan bahwa sewa menyewa ialah suatu perjanjian dengan mana pihak yang satu mengikatkan dirinya kepada pihak yang lain untuk kenikmatan dari sesuatu barang, selama suatu waktu terterntu dan dengan pembayaran sesuatu harga, yang oleh pihak tersebut belakangan itu disanggupi pembayarannya.

$\begin{array}{crr}\text { Untuk } & \text { memberikan } \\ \text { gambaran } & \text { awal } & \text { terhadap }\end{array}$
permasalahan ini, perlu disampaikan bahwa para pihak dalam perjanjian ini adalah Murtala selaku pihak pertama yaitu sebagai pihak pemilik rumah atau yang menyewakan selanjutnya pihak kedua adalah Rusdi Arasyid sebagai pihak penyewa. Dalam pelaksanaan perjanjian sewa menyewa ini, pihak kedua mewakilkan semua urusan kepada anaknya yang bernama Zulfikar Hanif dikarenakan rumah ini disewakan oleh pak Rusdi untuk kepentingan rumah tinggal anaknya selama kuliah.

Para pihak dalam perjanjian ini telah menyepakati beberapa klausula yang dirumuskan dan dituangkan dalam Surat Perjanjian Sewa Menyewa Rumah (terlampir). Surat ini ditandatangani oleh para pihak pada tanggal 22 Desember 2018 dan dilatarbelakangi oleh alasan dan pertimbangan dari pemilik rumah untuk menghindarkan pihak penyewa dari melakukan berbagai tindakan atau perbuatan yang melanggar dari ketentuan sewa yang akan menyebabkan kerugian bagi pihaknya, sedangkan pembayaran uang muka sebesar Rp. 2.500.000,(dua juta lima ratus ribu rupiah) sebagai tanda jadi perjanjian ini sudah disepakati bersama oleh kedua belah pihak dan dibayarkan oleh Pihak Kedua pada tanggal 19 Desember 2018.

Namun, Pihak Kedua tidak dapat langsung memasuki rumah sewa dikarenakan permintaan tambahan waktu dari Pihak Pertama untuk melakukan penggantian kunci rumah. Pihak Kedua sendiri - pada tanggal 8 Januari 2019 - kemudian memutuskan untuk mulai masuk ke rumah sewa, dan ternyata mendapati bahwa rumah sewa dimaksud sudah ditempati oleh 
orang lain, dan berdasarkan informasi yang diterimanya dari pihak ketiga dimaksud, ternyata rumah tersebut sudah beliau beli dari Pihak Pertama (Murtala, Zulfikar Hanif, 2019). Memperhatikan kondisi ini maka dapat kita ketahui bahwa ternyata walaupun pembuatan perjanjian sewa menyewa dimaksud adalah inisiatif dari Pihak Pertama untuk melindungi dirinya dari kemungkinan kerugian atau wanprestasi yang dilakukan oleh Pihak Kedua, ternyata dalam pelaksanaannya pihak pemilik rumah sendirilah yang melakukan pelanggaran terhadap perjanjian yang sudah mereka sepakati.

Dalam hal ini kesepakatan tertulis yang dibuat oleh para pihak pada prinsipnya patut diapresiasi karena adanya niat dan komitmen dari para pihak untuk merumuskannya secara tertulis sehingga menghindarkan dari kemungkinan kurangnya alat bukti akibat dari timbulnya berbagai permasalahan seiring dengan pelaksanaan perjanjian jika dibandingkan dengan perjanjian yang dibuat hanya secara lisan. Perjanjian yang disepakati oleh para pihak adalah perjanjian sewa menyewa, dan untuk menelaah halhal yang terkait dengan pelaksanaan dari hubungan hukum sewa menyewa tersebut maka pada bagian berikut dari tulisan ini akan disampaikan klausula-klausula yang telah disepakati oleh para pihak sebagaimana telah dituangkannya dalam Surat Perjanjian Sewa Menyewa. Surat ini melihat pada strukturnya dibuat secara sederhana, namun telah memenuhi aspek-aspek dasar yang ada dalam suatu kontrak tertulis.

Berbicara tentang wanprestasi sebagaimana yang terjadi dalam pelaksanaan perjanjian ini, maka dapat diketahui bahwa wanprestasi terjadi apabila ada salah satu pihak melakukan perbuatan ingkar janji sehingga menimbulkan kerugian bagi pihak lainnya. Suatu perjanjian dianggap terlanggar karena terjadi permasalahan antara keduanya dan salah satu pihak tidak bisa menerima kerugian tersebut. Hal demikian sebenarnya sering terjadi dalam perjanjian sewa menyewa. Wanprestasi tidak akan timbul apabila salah satu pihak tidak lalai atau dalam hal ini tidak secara sengaja melakukan pelanggaran terhadap pelaksanaan kewajibannya terhadap perjanjian yang telah sama-sama disepakati. Dalam hal terjadinya wanprestasi, maka akan memberikan akibat hukum terhadap pihak yang melakukannya dan membawa konsekuensi terhadap hak bagi yang telah dirugikannya.

Wanprestasi dalam kasus ini adalah tidak terlaksananya suatu prestasi yang terjadi disebabkan 
salah satu pihak tidak melakukan kewajibannya sesuai dengan isi perjanjian. Seseorang melakukan wanprestasi dalam suatu perjanjian kadang-kadang tidak mudah untuk membuktikannya, apalagi jika perjanjiannya hanya dilakukan secara lisan oleh kedua belah pihak dan tidak didukung oleh alat bukti lainnya. Dalam hal terjadinya wanprestasi maka mewajibkan pihak tersebut untuk memenuhi prestasi pokoknya dan dibebani dengan sanksi tambahan baik berupa pemberian denda, bunga dan lain-lain ganti kerugian yang dimintakan oleh pihak yang dirugikan.

\section{Menurut ketentuan KUH} Perdata, sanksi-sanksi akan diberikan kepada pihak yang melakukan wanprestasi yaitu berupa:

1. Pembayaran ganti rugi sesuai dengan dasar hukumnya dalam Pasal 1243 KUHPerdata yang berbunyi bahwa penggantian biaya, kerugian dan bunga karena tak dipenuhinya suatu perikatan mulai diwajibkan, bila debitur, walaupun telah dinyatakan lalai, tetap lalai untuk memenuhi perikatan itu, atau jika sesuatu yang harus diberikan atau dilakukannya hanya dapat diberikan atau dilakukannya dalam waktu yang melampaui waktu yang telah ditentukan.

2. Pembatalan perjanjian sesuai dengan Pasal 1266 KUHPerdata yang berbunyi bahwa pihak yang terhadapnya perikatan tidak dipenuhi, dapat memilih, memaksa pihak yang lain untuk memenuhi persetujuan, jika hal itu masih dapat dilakukan, atau menuntut pembatalan persetujuan, dengan penggantian biaya, kerugian dan bunga.

3. Peralihan resiko sudah diatur dalam Pasal 1460 KUHPerdata yang berbunyi bahwa resiko atau barang yang tertentu yaitu resiko berpindah kepada pembeli sejak adanya kata sepakat, walaupun penyerahan barang belum dilakukan. Nilai keadilan dalam hal risiko yang terjadi menurut hukum Islam ditanggung oleh pihak yang tak mampu memenuhi akad (lalai).

4. Membayar biaya perkara apabila sampai diperkarakan dimuka hakim, mengenai hal ini telah diatur dalam Pasal 183 HIR yang berbunyi bahwa banyaknya biaya perkara, yang dijatuhkan pada salah satu pihak harus disebutkan dalam keputusan. Aturan itu berlaku juga tentang jumlah biaya, kerugian dan bunga 
uang, yang dijatuhkan pada satu pihak untuk dibayar kepada pihak yang lain (Kitab Undang-Undang Hukum Perdata, 2005).

Perjanjian sewa menyewa yang dibuat pemilik rumah dengan penyewa rumah dalam kasus ini jelas tidak melibatkan pihak lain sebagai saksi dan tidak melibatkan pihak notaris karena dibuat hanya di bawah tangan antara pihak penyewa dan pemilik rumah saja. Padahal dalam ketentuannya, semua perjanjian yang dibuat secara sah mengikat para pihak layaknya undang- undang. Pada setiap terjadinya perjanjian, maka akan timbul hubungan hukum yang terjadi antara para pihak karena telah saling mengikatkan diri mereka dan pada prinsipnya tidak boleh diingkari oleh keduanya.

Hubungan hukum ialah hubungan antara dua atau lebih subyek hukum. Dalam hubungan hukum ini hak dan kewajiban para pihak yang satu berhadapan dengan hak dan kewajiban yang lain. Kewajiban pemilik rumah adalah memberikan hak sewa atas rumah dimaksud kepada penyewa selama jangka waktu yang disepakati, dan pihak penyewa wajib membayarkan uang sewa yang telah disepakati bersama beserta kewajibankewajiban lainnya sebagaimana yang telah ditetapkan secara khusus di dalam surat perjanjiannya maupun sebagaimana yang diatur dalam KUH Perdata - misalnya saja kewajiban untuk menjadi bapak rumah yang baik.

Pada dasarnya, hukum memiliki dua segi, yaitu segi kekuasaan/kewenangan atau hak (bevoegheid) dan segi kewajiban (plicht). Dalam segi kekuasaan, para pihak tersebut yaitu mengikatkan suatu hubungan yang sesuai atas kekuasaannya sendiri. Sedangkan segi kewajiban yaitu para pihak mempunyai hubungan hukum yang harus dipatuhi atas kewajibannya tersebut. Hak dan kewajiban ini timbul akibat adanya suatu peristiwa yang diatur oleh hukum, seperti yang tercantum dalam Pasal 1457 KUHPerdata tentang perikatan, yang timbul akibat adanya suatu perjanjian. Dalam hubungan hukum mempunyai ciri-ciri yang harus dipahami yaitu sebagai berikut:

1. Adanya orang-orang yang hak atau kewajibannya saling berhadapan.

2. Adanya obyek yang berlaku berdasarkan hak dan kewajiban.

3. Adanya hubungan antara pemilik hak dan pengemban kewajiban, atau adanya hubungan terhadap objek yang bersangkutan (R. Subekti,2005).

Akibat hukum adalah akibat yang ditimbulkan oleh peristiwa hukum disebabkan karena suatu 
peristiwa hukum atau juga oleh karena adanya perbuatan hukum, sedangkan suatu perbuatan hukum juga dapat melahirkan suatu hubungan hukum, maka akibat hukum juga dapat dimaknai sebagai suatu akibat yang ditimbulkan oleh adanya suatu perbuatan hukum atau hubungan hukum. Menurut Pipin Syarifin akibat hukum adalah segala akibat yang terjadi dari segala perbuatan hukum yang dilakukan oleh subyek hukum terhadap obyek hukum atau akibat- akibat lain yang disebabkan karena kejadiankejadian tertentu oleh hukum yang bersangkutan telah ditentukan atau dianggap sebagai akibat hukum. Akibat hukum inilah yang kemudian melahirkan suatu hak dan kewajiban bagi subyek hukum (Pipin Syarifin, 2009).

Secara umum, akibat hukum yang harus diterima oleh pihak pelaku wanprestasi yaitu sebagai berikut:

1. Debitur diharuskan membayar ganti rugi.

2. Kreditur dapat minta pembatalan perjanjian melalui pengadilan.

3. Kreditur dapat minta pemenuhan perjanjian, atau pemenuhan perjanjian disertai ganti rugi dan pembatalan perjanjian dengan ganti rugi. Wujudnya suatu akibat hukum itu timbul karena suatu peristiwa hukum. Akibat dari wujud tersebut yaitu sebagai berikut:

1. Berubahnya atau lenyapnya suatu keadaan hukum.

2. Berubahnya atau lenyapnya suatu hubungan hukum antara dua atau lebih subyek hukum, dimana hak dan kewajiban pihak yang satu berhadapan dengan hak dan kewajiban pihak yang lain.

3. Lahirnya sanksi apabila dilakukan tindakan yang melawan hukum (L.J. Van Apeldoorn, 2001).

Akibat hukum itu terjadi apabila salah satu pihak tidak memenuhi prestasi yang telah dibuatnya sehingga merugikan pihak lain. Namun, karena pihak yang dirugikan tidak menerima atas perbuatan demikian, maka akan menuntut pihak tersebut sehingga pihak yang membawa kerugian itu harus menerima resiko atau akibat hukum atas perbuatannya. Akibat hukum yang berikan oleh pihak dirugikan bisa saja berupa resiko denda atau sanksi sebagai peringatan untuk pihak yang membawa kerugian. Dengan adanya peringatan ingkar janji itu, maka para pihak akan mengingat bahwa dirinya telah mengikatkan sebuah perjanjian yang sah dan berkekuatan hukum. 
Surat perjanjian sewa menyewa rumah dalam tersebut dibuat oleh pemilik rumah kemudian ditandatangani oleh pihak penyewa di atas materai dengan tujuan yaitu untuk mempunyai kekuatan hukum apabila suatu hari nanti pihak penyewa melakukan pelanggaran dalam pembayaran sewa menyewa. Tetapi, ternyata yang tidak sengaja dalam melakukan permasalahan tersebut justru pemilik rumah. Meski demikian, pihak pemilik rumah menyatakan bahwa dirinya bukannya mempunyai itikad tidak baik dan menyatakan bahwa dirinya akan tetap bertanggungjawab atas perbuatannya tersebut dan akan mengganti kerugian yang dirasakan oleh pihak penyewa (Murtala, 2019).

Secara umum, para pihak dalam perjanjian sewa menyewa lebih memilih untuk menyelesaikan permasalahannya dalam bentuk musyawarah diantara keduanya, sampai mencapai kesepakatan. Terkait dengan wanprestasi dalam studi ini yang dilakukan oleh bapak Murtala, pada dasarnya telah melanggar unsur essensialia dari perjanjian sewa menyewa. Dalam perjanjian dimaksud telah dimuat juga pengaturan terkait dengan larangan bagi kedua belah pihak untuk melakukan pelanggaran yang menyatakan "kedua belah pihak tidak boleh melanggar isi perjanjian yang telah disepakati dalam hal sewa menyewa rumah tersebut" dan "apabila salah satu pihak melakukan pelanggaran isi perjanjian, maka pihak tersebut harus menggantikan kerugian sesuai dengan yang diderita oleh pihak yang menerima kerugian itu".

Memperhatikan kedua poin sebagaimana yang telah diatur didalam perjanjian tersebut menjadi dasar penyelesaian sengketa diantara keduanya. Proses penyelesaian sengketa ini dilakukan oleh para pihak tanpa melibatkan pihak lainnya, baik dari pihak aparatur dusun maupun aparatur gampong lainnya. Kedua belah pihak memusyawarahkan hal-hal terkait. Berdasarkan musyawarah ini disepakati hal-hal sebagai berikut: Pertama, kedua belah pihak sepakat untuk menyelesaikan masalah ini dan tidak memperpanjangnya lagi dalam sengketa- sengketa lainnya. Kedua, Pihak Yang Menyewakan mengembalikan uang panjar yang sudah dibayarkan oleh Pihak Penyewa secara penuh. Ketiga, sebagai komitmen dan rasa terima kasih pihak yang menyewakan, dirinya memberikan uang sebesar Rp. 300.000,- (tiga ratus ribu rupiah) kepada pihak penyewa.

Dalam kasus ini menunjukan bahwa pola musyawarah dan mediasi sebagai salah satu cara menyelesaikan permasalahan pada dasarnya dapat ditempuh atas dasar kesadaran danpara pihak 
dibandingkan melalui jalur pengadilan. Hal ini kiranya menjadi praktik baik dalam penyelesaian masalah di masyarakat Aceh yang semakin komplek dan dinamis ini. Apalagi ketika Pemerintah Aceh telah membuat regulasi khusus terkait dengan pelaksanaan peradilan adat.

\section{KESIMPULAN}

Berdasarkan uraian yang telah dipaparkan sebelumnya, maka dapat ditarik kesimpulan sebagai berikut: Bahwa hubungan hukum yang terjadi diantara para pihak dalam studi ini adalah dalam bentuk perjanjian sewa menyewa terhadap obejek 1 (satu) unit rumah yang terletak di Dusun A Desa Panggoi Kecamatan Muara Dua Kota Lhokseumawe, dengan harga sewa sebesar Rp. 14.500.000,- (empat belas juta lima ratus ribu rupiah) dan masa sewa selama 3 (tiga) tahun. Berdasarkan hubungan hukum ini telah mengikat para pihak untuk melaksanakan hak dan kewajibannya masing-masing, yang dituangkan dan disepakati secara tertulis oleh para pihak dalam Perjanjian Sewa Menyewa. Dalam pelaksanaan perjanjian ini, diketahui bahwa Pihak Yang Menyewakan melakukan wanprestasi dari awal dilaksanakannya perjanjian, yaitu dalam bentuk tidak memenuhi kewajibannya dengan tidak memberikan hak sewa atas rumah dimaksud bahkan rumah tersebut telah dijualnya kepada pihak lain tanpa adanya pemberitahuan yang layak kepada pihak penyewa. Terhadap wanprestasi yang telah dilakukan tersebut mengakibatkan timbulnya akibat hukum yang di dalam ketentuan KUH Perdata mewajibkan orang tersebut untuk membayar ganti rugi. Terhadap permasalahan wanprestasi tersebut, para pihak memilih untuk menyelesaikan permasalahannya dengan cara mediasi dan musyawarah diantara keduanya dan mencapai kesepakatan bahwa uang panjar dibayarkan kembali oleh pihak yang menyewakan disertai dengan sejumlah uang tertentu yang diberikannya sebagai kompensasi bagi pihak penyewa. Pemilihan mekanisme mediasi ini dilakukan oleh para pihak atas kesadarannya sendiri dan dilandasi oleh itikad baik serta komitmen untuk tidak memperpanjang permasalahan.

\section{E. SARAN}

\begin{tabular}{lrr}
\multicolumn{2}{c}{ Berdasarkan pada hasil } \\
penelitian, maka studi ini
\end{tabular} menyarankan kepada para pihak yang terlibat dalam perjanjian maupun masyarakat umum yang akan mengikatkan diri dalam perjanjian : Untuk menyusun naskah perjanjian yang tidak hanya memuat keseluruhan clausula essensialia dalam perjanjian, namun juga memuat clausula naturalia dan acsidentalia serta melibatkan para 
saksi didalam penandatanganan kontrak. Hal ini sebagai langsung prefentif dalm hal tejadinya kerugian wanprestasi maupun perbuatan melawan hukum. Begitu pula dalam hal terjadinya wanprestasi dan perbuatan melawan hukum maka keberadaan saksi penting untuk dilibatkan dalam perjanjian dimaksud. Selanjutnya studi ini juga menyarankan kepada pembaca dan masyarakat umum di dalam melaksanakan perjanjian dalam bentuk perjanjian apapun kiranya dapat memenuhi asas-asas perjanjian dengan baik, utamanya adalah asas itikad baik harus menjadi landasan awal di dalam membuat perjanjian sampai dengan pelaksanaan perjanjian. Selain itu asas konsensualisme juga harus dikedepankan sehingga mencegah terjadinya kemungkinan pelanggaran atas syarat sah subjektifnya perjanjian. Selain juga perlu memahami dan mengimplementasikan asas-asas perjanjian lainnya. Dalam hal terjadinya permasalahan terkait dengan pelaksanaan suatu perjanjian-misalnya saja wanprestasi ataupun perbuatan melawan hukum, hendaknya para pihak dan masyarakat umum lebih mengedepankan prinsip penyelesaian masalah dengan mekanisme mediasi yang dalam realitasnya lebih menguntungkan bagi para pihak, baik dari segi waktu maupun materi.

\section{DAFTAR PUSTAKA}

Agus Suki Widodo, 2004, Tanggung Jawab Para Pihak dalam Pelaksanaan Perjanjian Sewa Menyewa Kendaraan Bermotor di Surakarta, Skripsi, Fakultas Hukum Universitas Diponegoro, Semarang

Ahmadi Miru, 2007, Hukum Kontrak dan Perancangan Kontrak, PT. Raja Grafindo Persada, Jakarta

A Michael Huberman, 2007, Analisis Data Kualitatif, Universitas Indonesia Press, Jakarta Amiruddin, 2012, Pengantar Metode Penelitian Hukum, PT. Raja Grafindo Persada, Jakarta A Moegni Djojodirdjo, 1982, Perbuatan Melawan Hukum, Pradnya Paramita, Jakarta

Baharudin Muhammad Hasan, 2017, Praktik Perjanjian Sewa Menyewa Rumah Toko (Ruko) Secara Lisan Di Kota Palangka Raya Ditinjau Dari Hukum Perdata, Skripsi, Fakultas Syari'ah Progam Studi Hukum Ekonomi Syariah, Institut Agama Islam Negeri, Palangka Raya. http://repositori.uinalauddin.ac.id/3445/1/skripsi_lengkap baharuddin.29.pdf

Djaja S Meliala, 2012, Penuntun Praktis Hukum Perjanjian Khusus Jual-Beli, Sewa Menyewa, PinjamMeminjam, Nuansa Aulia, Bandung

Djoko Supadmo, 1995, KetentuanKetentuan dan Komentar Mengenai Jual Beli, Tukar Menukar, Sewa Menyewa, Dalam Praktek Teknik Pembuatan Akta, Bina Ilmu, Surabaya

Eryk Triyono, 2015, Tanggung Jawab Para Pihak Dalam Perjanjian Sewamenyewa Rumah (Kos-Kosan) Di Kota Mataram, Skripsi, Fakultas Hukum Universitas Mataram, 
Tanggung-Jawab-Para-Pihak-DalamPerjanjian-Sewamenyewa- Rumah(Kos-Kosan)-Di-KotaMataram.pdf/id.com.

Fuadi, Munir, 2007, Hukum Kontrak (Dari Sudut Pandang Bisnis), Citra Aditya Bakti, Bandung Handri Rahardjo, 2009, Hukum Perjanjian di Indonesia, Pustaka Yustisia, Jakarta

Ishaq, Dasar-Dasar Ilmu Hukum Cet. I, Sinar Grafika Jakarta, 2008, hlm. 43

J. Satrio, 1993, Hukum Perikatan Pada Umumnya, Alumni, Bandung 